\title{
The Application of Mobile Learning for University Students in the Pancasila Education Modul in Developing Character of Students' Empathy
}

\author{
Sarkadi $^{1, *}$, Asep Rudi Casmana1, Ucu Cahyana ${ }^{2}$, Maria Paristiowati ${ }^{2}$ \\ ${ }^{1}$ Department of Pancasila and Civic Education, Faculty of Social Science, Universitas Negeri Jakarta, Indonesia \\ ${ }^{2}$ Department of Chemistry Education, Faculty of Mathematics and Natural Science, Universitas Negeri Jakarta, Indonesia
}

Received April 22, 2020; Revised May 27, 2020; Accepted June 26, 2020

\section{Cite This Paper in the following Citation Styles}

(a): [1] Sarkadi, Asep Rudi Casmana, Ucu Cahyana, Maria Paristiowati , "The Application of Mobile Learning for University Students in the Pancasila Education Modul in Developing Character of Students' Empathy," Universal Journal of Educational Research, Vol. 8, No. 9, pp. 3825 - 3833, 2020. DOI: 10.13189/ujer.2020.080905.

(b): Sarkadi, Asep Rudi Casmana, Ucu Cahyana, Maria Paristiowati (2020). The Application of Mobile Learning for University Students in the Pancasila Education Modul in Developing Character of Students' Empathy. Universal Journal of Educational Research, 8(9), 3825 - 3833. DOI: 10.13189/ujer.2020.080905.

Copyright (C2020 by authors, all rights reserved. Authors agree that this article remains permanently open access under the terms of the Creative Commons Attribution License 4.0 International License

\begin{abstract}
The main purpose of this study is to improve students' empathy attitudes in Pancasila education courses using applications in mobile phones. It is a tool application or media that is used by educators to be able to transfer knowledge to their students. This is used to be able to increase the interaction and learning motivation of students, so they can obtain maximum learning resources. The name of the application is Pancasila Mobile learning, and it is available on Playstore for Android users and web-based page. Meanwhile, the empathy characters need to be developed by the school to be able to grow in students. As such, this study focuses on growing empathy by using mobile learning applications. The research method used is quantitative. The data collection technique used was an online questionnaire, which was filled by 119 students at universities in Jakarta. They are students who have already or are studying Pancasila in college. The results of this study indicate that the use of mobile learning applications in learning Pancasila in the classroom can increase empathy attitudes towards students. They can carry out positive activities, and feel pleasure and comfort when using mobile learning applications in the learning process. Thus, the use of mobile learning needs to be continuously developed by educators both in universities and schools.
\end{abstract}

Keywords Students, Empathy, Mobile Learning, Pancasila, Higher Education

\section{Introduction}

Mobile learning is the learning media that probably can be utilized during studying at the university(Traxler, 2009). With the latest technological developments, it is possible for the students to be able to use the learning process with a mobile phone. The experts try to define the meaning of mobile learning that can be used as a way to attract the diversity of students to improve the learning process (Martin \& Ertzberger, 2013). Clark Quinn (2000) has argued that the interaction of students in the application can access a wide range of resources as well as improve the effectiveness of learning media. What is more, he also argues that the independent learning style can probably appear when students use this mobile learning application. Then, it can be concluded that the mobile tool in the smartphone is considered to be the learning medium that can help students to find the information and communication among others (Crompton \& Burke, 2018; Marwan, Madar, \& Fuad, 2013).

The use of mobile learning in the university can support distance learning. It is because students can focus on the module given by their lecturer out of the classroom (Benali \& Ally, 2020). The tool that is needed by the students to 
utilize the learning resource is application. It is used as one of the things or one of the media to be able to teach certain methods to students. At the tertiary level, mobile learning can be used to teach several subjects, so that students can naturally improve the learning process by using applications. However, to use mobile learning in the learning process, it takes several abilities or skills that need to be possessed, both by the students and by the teaching staff (Kaliisa \& Michelle, 2019). In order to use the application, some students and teachers need to learn how to connect and have a wide range of sources to improve the skill (Grant, 2019; Alasmari \& Zhang, 2019).

The use of mobile learning has many benefits. According to several previous studies, the benefits of mobile learning are to be able to increase the involvement, motivation, and enthusiasm of students to learn (Anohah, Oyelere, \& Suhonen, 2017; Yang, Zhou, \& Cheng, 2019). In addition, mobile learning can also be used as a way to be able to improve self-sharing, a sense of belonging to learning, and motivation to learn. Third, mobile learning can be used to improve timeliness and attendance in learning. Fourth, mobile learning can also be used as a way to increase participation in extracurricular activities. But in this study, mobile learning is used to be able to foster empathy attitudes of students in studying Pancasila education courses (Sarkadi \& Casmana, 2020).

The character of empathy is considered to be important for the students. Empathy among students can help increase a good relationship among the students. For instance, during the pandemic COVID-19 circumstances, all people need to support each other, including the students. When they stay at home and cannot meet up in real life, such as in the classroom, the use of mobile learning can help them to be connected. As such, the benefit of using mobile learning for students can help students to connect (Anohah, Oyelere, \& Suhonen, 2017).

In the current era of globalization, the existence of the character of the Indonesian Nation has declined. Much deviant behavior occurred among the Indonesian people, especially among adolescents or students. The decline is in attitudes that are in accordance with values and norms and Pancasila is one of the characteristics of the deterioration of character. Many Indonesian teenagers tend to glorify western culture compared to the Indonesian culture. Foreign cultures that are accepted are not completely selectable. One example of behavior from foreign cultures that enter Indonesia and erode a sense of brotherhood is a lack of empathy for others (Martin \& Ertzberger, 2013; Marwan, Madar, \& Fuad, 2013).

This is due to the lack of attention from the family and the role of education in building the character of adolescents, especially the character of empathy for people. There are still many families that do not give enough attention and affection and early learning to children so that the formation of the child's character is not fully developed properly (Suhadi, Syafrudin, \& Casmana, 2020). The role of education still lacks in the inculcation of character values in children.

Whereas the formation of a child's character starts from the family environment, including that forming an attitude of empathy can also start from the family. The family should instill positive values such as honesty, responsibility, empathy for fellow tolerance, which can be embedded so as to form the character of children (Grant, 2019).

The role of schools cannot be separated into building the characteristics of adolescents. At school, children are given education about values that should be able to build adolescent character in accordance with Pancasila. The rules that exist in the school also form a disciplined adolescent person so that the possibility of child abuse will be reduced (Sumadi \& Casmana, 2020). One of the rules that can be applied by the school policy is using the mobile application for students to help them connect one another.

In tertiary institutions, one of the subjects that require the use of mobile learning is the Pancasila Education course. This course focuses on studying the history of the formulation of Pancasila, to the application of Pancasila in everyday life. With the use of mobile learning, students can easily use it as a way of learning in their homes. In addition, Pancasila Education courses can also improve character or personality based on Pancasila characteristics. Therefore, the use of mobile learning is expected to be used in Pancasila education courses.

Based on the background of the study mentioned above, the research questions are divided into two main questions. These are "What are the learning content of Pancasila mobile that can affect the feeling of empathy? and why the character of empathy should be developed among students in school?" This research focuses on the use of mobile learning applications in learning activities of Pancasila Education in increasing empathy attitudes towards students. Thus, even though the learning process is carried out remotely, interaction from students can be carried out, and manifested and empathy begins to grow.

\section{Literature Review}

\section{The Concept of Mobile Learning}

Mobile learning application has become a need for every student across the world. This is because the tool can help students and teachers to learn in distance learning. Students will be able to receive a learning content, while teachers can transfer their knowledge using that application (Park, Lee, \& Kim, 2018; Dolawattha, Pramadasa, \& Jayaweer, 2019). Mobile learning application is considered to be very easy to use, and cheap for the students. The tool can be obtained from the play store as an android platform. So that it really helps students to improve their knowledge and tools. (Zid, Alkhudri, Casmana, Marini, \& Wahyudi, 
2020).

The application is a media that is used by educators to be able to transfer knowledge to their students. This is used to be able to increase the interaction and learning motivation of students, so they can obtain maximum learning resources (Kärki, Keinänen, Tuominen, \& Hoikkala, 2018; Moorthy, Yee, T'ing, \& Kumaran, 2019). There is teaching material that is not suitable to adopt the concept of mobile learning, among others: material that is "hands-on", skills as a dentist, the art of music especially creating songs, interview skills, teamwork such as social science and materials that require the expression of expressions such as dance.

The mobile learning application is considered to be mentioned as a mobile computing device. It is the device in the form of a digital phone. In addition, this mobile phone is considered to be very small, so that the students can bring it everywhere and study wherever they want. It can be used by the students to access the content, watch the video, fill the form, as well as the exams. The teachers have developed this advanced technology that can be used for students to learn something new in Pancasila (Zid, Casmana, \& Hijrawadi, 2020).

Meanwhile, another expert argues that the learning application is often defined as e-learning through mobile computing devices. Mobile learning is the delivery of electronic learning material on mobile computing tools so that it can be accessed from anywhere and at any time. In general, the intended mobile devices are smartphones, mobile phones, and PDA (Dolawattha, Pramadasa, \& Jayaweer, 2019; Aguayo, Cochrane, \& Narayan, 2017; Bai, 2019; Marwan, Madar, \& Fuad, 2013).

M-Learning can be grouped into several classifications, depending on several points of view (Kärki, Keinänen, Tuominen, \& Hoikkala, 2018). From the ICT technology used, m-learning can be classified based on the main indicators, namely the type of devices supported and the type of wireless communication used to access learning material and administrative information. According to the time the teacher and students share information, m-learning can be classified as advanced; systems that support synchronous learning, systems that support asynchronous learning, and systems that support synchronous and asynchronous learning as well.

In this research, the mobile learning application that will be used for students is in the Pancasila Education module. The application is already available on the Playstore for Android users. In addition, there is also a web-based page that can be used for the overall user. In addition, it will help students to increase not only student's knowledge but also the student's attitude during distance learning. In the mobile application, students can connect and share their knowledge as well as interact with them. Therefore, this research focuses on how mobile learning applications in the Pancasila Education module can increase the student's attitude towards empathy.

\section{Pancasila Education Modul}

Pancasila Education is one of the compulsory subjects studied by students in tertiary institutions. This course examines the history of the Nation's founders, the history of the formulation of state ideology, and how life or attitudes are in accordance with the ideology of Pancasila (Morfit, 1981). Law Number 20 the Year 2003 concerning the National Education System and also contained in the Decree of the Director-General of Higher Education Number 43 / DIKTI / KEP / 2006, explained that the objectives of the Pancasila material in the Personality Education signs are directed at the morals that are expected to manifest in daily life, namely behavior which radiates faith and piety towards God Almighty, the basic values of Pancasila, a sense of pride and patriotism in mastering, applying and developing technological knowledge and art with a full sense of responsibility and morality.

Educational objectives are defined as a set of responsible intellectual actions oriented towards students' competencies in their respective professional fields. Competencies of graduates of Pancasila education are a set of intellectual actions, full of responsibility as citizens in solving various problems in social, national, and state life by implementing thoughts based on Pancasila values. Intellectual property is reflected in the skills, accuracy, and success of action, while the nature of full responsibility is shown as the truth of the action seen from the aspects of science and technology, ethics or the appropriateness of religion and culture (Nishimura, 1995).

Pancasila is the five precepts which constitute a unity of a series of noble values, which is derived from the cultural values of Indonesian society, which are very diverse and diverse in the sense of BHINEKA TUNGGAL IKA which means unity in diversity. The object of philosophical material is to learn all the essence of something both concrete and abstract material Pancasila has several goals.

First, Pancasila has a goal as the basis of the state. It contains the understanding that Pancasila as the basis for managing government (Abdulkarim, Komalasari, Saripudin, \& Anggraini, 2020). The position of Pancasila as the basis of the state has the function and position as the country principle which is fundamental. It is permanent, strong and cannot be changed by anyone including the MMPR / DPR as the result of the general election. Second, Pancasila as the source of basic national law. In law the term "legal source" means the source of values, which is the cause of the emergence of the rule of law. So it can be interpreted as Pancasila as the Source of Basic National Law, namely all legal rules that apply in our country must not conflict and must be sourced from Pancasila (Nurdin, 2015).

Third, Pancasila as the view of Indonesian life. It implies that all the activities of daily life of the Indonesian people must be in accordance with the precepts of the Pancasila, because Pancasila is also a critique of the values that are owned and sourced from the life of the Indonesian people 
themselves. Fourth, Pancasila as the Noble Agreement of the Indonesian Nation. When Indonesian people rose to live alone as an independent nation, they people had agreed to make Pancasila as the State Foundation. The agreement was realized on August 18, 1945 with the ratification of the Pancasila as the Basis of the State by the PPKI, which represented the entire Indonesian Nation. The Five Pancasila as the State Ideology. It is a common goal of the Indonesian Nation that is implemented in realizing a just and prosperous society that is evenly distributed in a spiritual and material basis based on Pancasila in the Republic of the Republic of Indonesia which is independent, sovereign, united and sovereignty of the people in the atmosphere of a secure, peaceful, orderly and dynamic society, and in the environment of a free, friendly, orderly and peaceful world.

Finally, Pancasila as the Unifier of the Nation. The pluralism of the Indonesian Nation and the archipelago consists of various islands, it is very appropriate if Pancasila is made as a unified nation; this is because Pancasila values and universal values have enabled it to be able to coordinate all diverse and acceptable lives of all parties.

In order to produce students who live the values of Pancasila, students are expected to have the ability to take responsible attitudes in accordance with their conscience, have the ability to recognize life and welfare problems and ways and solutions, recognize changes in scientific development knowledge, technology and art, and have the ability to interpret historical events and national cultural values to promote the unity of Indonesia. Through Pancasila Education, citizens of the Republic of Indonesia are expected to be able to understand, analyse and answer the problems faced by the people of their Nation in a sustainable and consistent manner based on the ideals and goals of the Indonesian Nation (Fitch \& Webb, 1989; Sarkadi, Casmana, \& Rahmawati, 2020).

In essence, education is a conscious effort of the people and government of a country to ensure the survival of the Nation and the State, in a useful (related to spiritual ability) and meaningful (related to cognitive abilities and psychomotor education). In addition, education is expected to be able to anticipate the future of those who are constantly changing and are always related to the context of the dynamics of culture, Nation, state, and international relations. Higher education ignores the reality of global life which is described as a life change filled with paradoxical and dependent.

The ability of citizens of a country to live a life capable of anticipating development and meaningful and future changes greatly requires the provision of science, technology and art (IPTEKS) based on religious values and national cultural values. The basic values of the state will be guide and color the beliefs and guidelines of citizens' lives in the life of the nation and state society (Komarudin, Alkhudri, Ubedilah, Syaifudin, \& Casmana, 2019).

\section{Character of Empathy}

The term "empathy" comes from the Greek words "phatos" which means deep or strong feelings. In addition, the term "empathy" also comes from the word "einfuhlung" which is used by a German psychologist, which literally means entering the feelings of others (feeling into) (Rockwell, Vidmar, Harvey, \& Greenwo, 2019)

Empathy is one's ability to understand the feelings and emotions of others and the ability to imagine oneself in another's place. The ability for empathy can begin to be possessed when someone occupies the end of early childhood (6 years) so that it can be said that all individuals have the basic ability to empathize, it's just different levels of depth and how to actualize it. Empathy should already be owned by teenagers, because the ability to empathize has begun to emerge in early childhood (Meyers, Rowell, Wells, \& Smith, 2019).

Further explained that empathy is the ability to feel the emotional state of others, feel sympathetic, and try to solve problems and take other people's perspectives. Empathy is very important for healthy relationships and overall well-being. In the affective component, empathy is an emotional response to the pressure of others and can be divided into two forms: personal distress and empathic concern (Bullough Jr, 2019)

Bullough JR (2019) defines empathy as which refers to two cognitive and affective aspects. 1) Empathy as cognitive awareness of the internal conditions of others (thoughts, feelings, perceptions, and intentions) and 2) Affective responses made for others. Then Hoffman also defines affective empathy as a meeting between observers and feelings towards others. Most research on affective empathy as a prosocial motive focuses on empathic distress because prosocial moral action raises the urge to help someone who is uncomfortable, angry, suffering, and so on (Bullough Jr, 2019).

Formulating empathy is the ability to put oneself in the place of others so that they can understand their needs and feelings. In addition, empathy can be considered as a continuation of tolerance. Empathy can be interpreted as the ability to feel what other people feel by an individual or a group of people.

A person's ability to recognize others or care, shows one's empathy ability. Individuals who have the ability to empathize are better able to pick up on hidden social signals that signal what others need so that they are more able to accept other people's perspectives, be sensitive to other people's feelings and more able to listen to others (Mul, Stagg, Herbelin, \& Aspell, 2018).

Another expert who argues about empathy is Nancy Eisenberg who states that empathy is an affective response that comes from capturing or understanding emotional states or other conditions, and which is similar to other people's feelings. Empathy is also the ability to put oneself in the position of others and be able to live up to the experiences of others. Arrest or understanding of the 
emotional state is where empathy occurs when a person can feel what other people feel, but still does not lose his own reality. This means that emotions that are moved to feel what others feel do not necessarily make a person lose his identity and attitude. Someone still has self integrity (Cuzzo, Larson, \& Mattsso, 2017).

Empathy in relation to emotional intelligence is a very important component. Empathy is built on the basis of self-awareness, the more open a person is to his emotions, the more skillful a person also reads other people's feelings. So empathy requires the distinction between emotions and personal desires from the emotions and desires of others. Accuracy in empathy is greatly influenced by one's ability to interpret information given by others about their internal situation that can be known through their behavior and attitudes.

As for the concept of empathy according to Al-Hadith, that is, as with the words of Rasulullah SAW, " If people no longer care about the poor, show off their wealth, act like dogs (lick superiors, kick subordinates), and only make profits, then Allah brings four case: famine, the tyranny of the authorities, betrayal of law enforcement, and pressure from the enemy. "(HR Ad-Dailami). We can interpret that in the hadith, the Prophet taught us all to have an empathy attitude. So, it is not only our love that we feel, but God's love we also feel. So, it can be concluded that empathy is a person's attitude ability from self-awareness in understanding others or a group, both in the form of cognitive and affective responses by sharing what other people feel.

\section{Method}

\section{Research Design}

Quantitative research is a method of research that is more directed at aspects of objectively measuring social phenomena. To take measurements, each social phenomenon is described in terms of several problem components, variables and indicators (Cohen, Manion, \& Morrison, 2013). This research focuses on descriptive methods. Descriptive method is a fact finding that uses the correct interpretation. In this research, it studies about the problems that exist within the community and the procedures used in the community in certain situations. Descriptive research is a type of method that describes an object and subject that are being studied without engineering, also includes the relationship of activities, views, attitudes and processes that influence in a phenomenon that occurs (Cohen, Manion, \& Morrison, 2013). In this study the focus is on the responses of students who are taking the Pancasila Education course in tertiary institutions using mobile learning. The student is a person who has used a mobile learning application in studying the basic concepts of Pancasila.

\section{Participants}

The respondents involved in this study were students who were pursuing higher education in Jakarta. The number of respondents was 119 people, each of whom was scattered in the Faculty of Social Sciences, the Faculty of Mathematics and Natural Sciences, the Faculty of Engineering and others. They are active students, who are taking Pancasila Education courses and using mobile learning applications in the learning process.

\section{Data Collection}

In research, data collection technique is an important factor for the success of research. This relates to how to collect data, who is the source, and what tools are used. In this study, the method used to collect data is a questionnaire. Questionnaire / questionnaire is a data collection technique that can be used by this research to collect the data and get participants respond. The number of questionnaires distributed to participants was 119 .

In addition, the simple random sampling was used to collect the data. It is because the simple random sampling technique is a way of taking samples or elements randomly, where each element or member of the population has the same opportunity to be selected as a sample. Therefore, every student of the university in Jakarta has an opportunity to fill the application form.

The questionnaire generally contains of two main ideas, which are about the use of mobile learning application and how it affects the character of empathy. In the first group of questionnaire, participants were asked about the experience of using mobile learning. In particular, they were asked of the feeling, the improved learning design, as well as content for the lecture. In addition, the second part of the questionnaire contains how the use of mobile learning application can affect the feeling of empathy towards among participants. It is important that the use of mobile learning application can actually help students to improve feeling of empathy.

\section{Data Analysis}

Descriptive statistics are statistics used to analyze data by describing or describing the data that has been collected as it exists without intending to make conclusions that apply to the public or generalizations. This research uses descriptive statistics in its analysis. Descriptive statistics can be used to describe sample data, and do not want to make conclusions that apply to populations where samples are taken. Regarding data with descriptive statistics, researchers need to first pay attention to the type of data. If the researcher has discrete data, the presentation of the data that can be done is to look for absolute frequency, relative frequency (looking for percentages), and looking for measures of central tendencies, namely: mode, median and mean.

Descriptive statistical functions, among others, classify a 
variable data based on the group, each of which has not been organized and is easily interpreted by the people who need information about the state of the variable. In this study, the main focus of the statistics used is to convey about how the use of the Pancasila mobile application can influence the attitude of students' empathy when studying Pancasila courses.

\section{Results and Discussion}

Mobile Learning is a learning model that is carried out between places or environments using technology that is easy to carry when the learner is in a mobile / cell phone condition (Kärki, Keinänen, Tuominen, \& Hoikkala, 2018). The level of penetration of mobile devices is very high, the level of use is relatively easy, and the price of devices that are increasingly affordable, compared to personal computer devices, is a driving factor that is increasingly expanding opportunities for the use or application of mobile learning as a new trend in learning, which forms a learning paradigm that can be done wherever and whenever (Moorthy, Yee, T'ing, \& Kumaran, 2019; Martin \& Ertzberger, 2013). There are three functions of Mobile Learning in learning activities in the classroom (classroom instruction), namely as a supplementary (optional) which is optional (optional), complementary (complementary), or substitute (substitution).

This study examines the use of mobile learning in learning Pancasila Education Courses conducted in tertiary institutions. Pancasila education provides understanding for students who are pursuing education at tertiary institutions. With mobile learning, empathy towards students can be done, even though learning is done in distance or distance learning. The results and discussion in this study were divided into two main categories, namely the learning content or the material presented, and the two students' empathy (Mul, Stagg, Herbelin, \& Aspell, 2018).

\section{The Learning Content}

The Pancasila Education course provides an explanation of the need for Pancasila lectures from various perspectives, several theories of origin, function and position, their relationship with the Preamble to the 1945 Constitution, thoughts and implementation and reform of Pancasila thought and implementation (Abdulkarim, Komalasari, Saripudin, \& Anggraini, 2020). In addition to the above, in the Pancasila Education course, current actual problems are also discussed, especially regarding racial intolerance, human rights, economic crisis, and various thoughts drawn from Pancasila values (Nurdin, 2015).

The Pancasila Education course modules are compiled based on the Outline of the Learning Program as stipulated in the Decree of the Director General of Higher Education Ministry of Education Number: 265 / DIKTI / 2000 on Improving the Core Curriculum for the Subject of
Pancasila Education Personality Development in Indonesian Universities. Based on the figure 1, it can be seen that the web-based learning resources is interesting to see, and make students interest to learn.

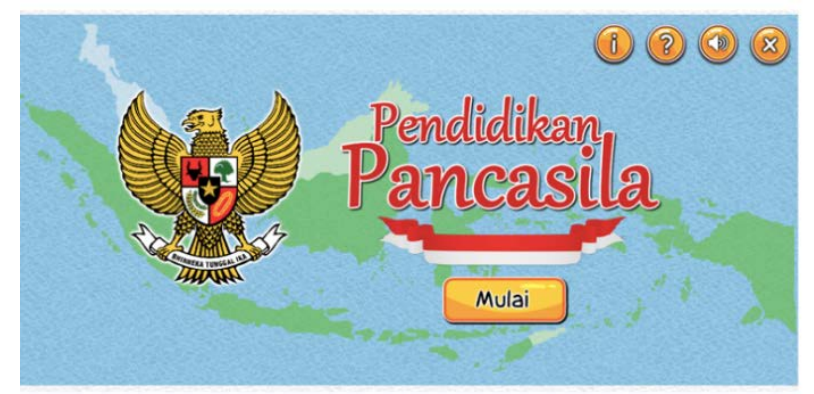

Figure 1. The surface of Pancasila education e-learning

The general objectives to be achieved by the Pancasila Education course are contained in the General Instructional Objectives, namely students are expected to have ten main understandings or characters. Among them are understanding the foundation given by the lectures of Pancasila, understanding the understanding of Pancasila, understanding scientific knowledge in general and Pancasila as scientific knowledge, understanding Pancasila as an object of scientific study, understanding of the theory of origin, understanding the theory of the origin of Pancasila culturally, the origin of formal Pancasila, and the origin of formal Pancasila, the dynamics of Pancasila as the basis of the state. Furthermore, students also need to understand and explain the function and position of Pancasila, both formally, namely Pancasila as the foundation of the Indonesian State and materially, namely Pancasila as the Nation's life view, understand and explain the relationship between Pancasila and the Opening of the 1945 Constitution and the intrinsic position of the Opening of the 1945 Constitution, understand and explain the thinking and implementation of Pancasila and Reform of thought and implementation of Pancasila. And finally the students can understand and explain the various actual problems today, especially the problems of racial, human rights, and economic crises as well as various thoughts drawn from the values of Pancasila to solve these problems (Nurdin, 2015).

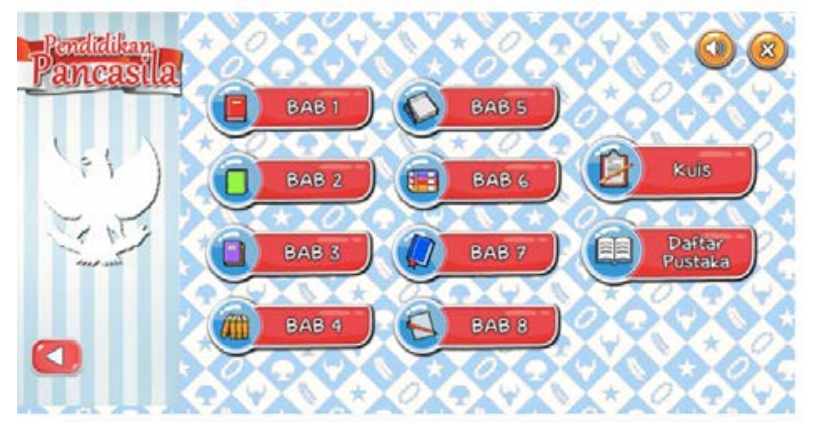

Figure 2. The list of Pancasila Education contents 
The burden of credit for Pancasila Education courses is two credits. Each credits has 3 modules so this course has 6 modules. The six module titles reflect the general instructional objectives discussed in the module. The figure 2 shows the content of Pancasila education module when the students try to use and operate the application.

To be able to study and understand concepts, these concepts are usually the learning methods used which are lectures. Lecturers in class deliver material by lecturing for two SKS. The method is said to be a boring method, moreover the study presented is about the history of Pancasila. Therefore, the need for a learning media is in the form of mobile learning that can be accessed by students.
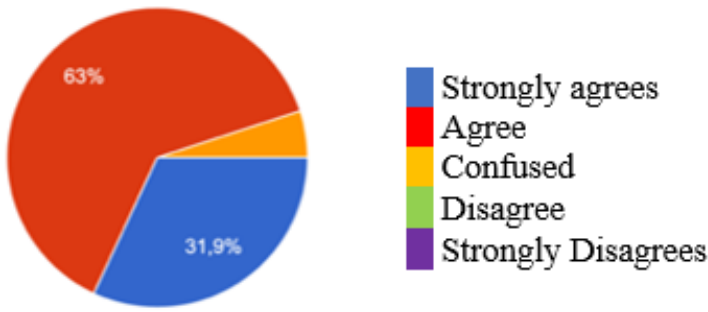

Figure 3. Students interest to the content in mobile learning

Some studies have confirmed that the use of mobile learning application for students can increase the level of excitement among them. This research also agrees that there are a lot of participants who are strongly agreed with statements. Based on the survey in figure 3, it can be seen that students are really interested to use mobile learning for improving their study, particularly Pancasila. Some of participants argue that the mobile learning application can probably replace the appearance of teacher or lecturer in classroom. So that, although students can study at home during the pandemic, they are still able to improve the knowledge.

In Finland, the distance learning is always encouraged by the school or universities. They support the teachers with a lot of application that can improve the learning experience. In a study regarding the improvement of learning experience, teachers argue that distance learning can help them to make student enjoy (Kaliisa \& Michelle, 2019; Bai, 2019). It is probably because students can feel enjoyment while studying at home.

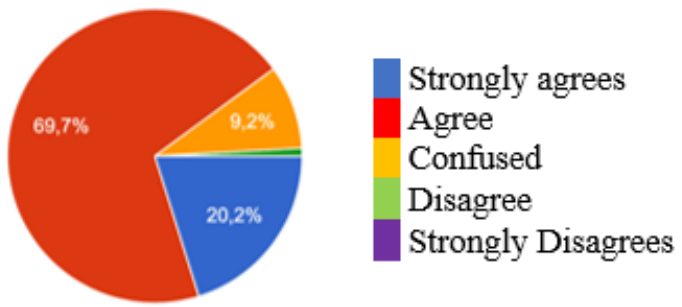

Figure 4. Students enjoy learning Pancasila using mobile learning

The second question is about the enjoyment of using mobile learning in Pancasila. The majority of participants agree that mobile learning makes them enjoy to study. In terms of figure 4 , students agree that one of the way to improve the happiness is learning by mobile application. Based on the literature review, one of the content that should be studied in Pancasila is history of founding father. Learning history is considered to be boring, particularly for those who dislike reading. By using this mobile learning, students really enjoy improving their knowledge using the mobile. This finding has confirmed several research studies which revealed that the use of mobile learning can improve the enjoyment of students, although they learn about history.

Based on these findings, it can be concluded that mobile learning can improve some enjoyment and excitement of the students who are learning about Pancasila, although the content that is learned by the students is about the history of founding father. In addition, the mobile learning should be supported by teacher to develop the future improvement.

\section{The Character of Empathy among Students}

The character of empathy is considered to be very important among students. It is because this kind of feeling can help improve peace among people in the community. People can help one another when someone needs help. The feeling of empathy means that people can express and respond the hope of other persons who are not telling verbally. Some people argue that the feeling of empathy and sympathy are same, however it is actually considered to be very different. The character of sympathy is considered to be what people think, and it is just appeared in their opinion. However, the character of empathy is not only feeling or thinking of good towards others, but they can take an action for helping people (Yang, Zhou, \& Cheng, 2019).

This definition of empathy has been supported by some experts. Even though some experts express the idea in different ways, generally the definition of empathy is truly same. In terms of Kohut, the feeling of empathy is considered to be a process in which people can be able to feel the same life condition as what other people experience. In addition, Kohut said that the feeling of empathy can be defined as the ability of thinking the others in a deepest life (Dolawattha, Pramadasa, \& Jayaweer, 2019).

Empathy can grow in the education process. Some experts say that empathy can be cultivated through a continuous process of communication and interaction. In distance learning situations, it is very difficult to be able to increase empathy, due to the lack of communication between one person and another. Therefore it is necessary to have a media that can unite and make people able to continue to interact.

One of the media in learning to be able to do distance learning process to be able to improve the character of empathy is to use mobile learning applications. This application can help students to continue to communicate and interact even though the learning process is not carried out in class. Therefore, it is necessary to develop the 
implementation of distance learning using the mobile learning application.

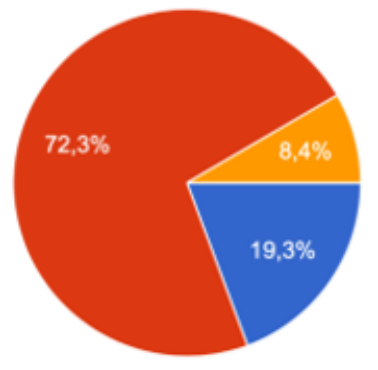

Strongly agrees

Agree

Confused

Disagree

Strongly Disagrees

Figure 5. The contents improve feeling of empathy

One of the way to improve feeling of empathy is communication. Several recent studies revealed that to improve empathy towards others, students should be encouraged to communicate with others. This form of communication can help students to have good relation with their friends. For example, when the lecturers ask students to do group work, they will work together and communicate with one another. When communication is built among students, the feeling of empathy will appear. Therefore, based on the figure three, the contents of Pancasila in mobile learning application can improve the feeling of empathy due to a lot of communication.

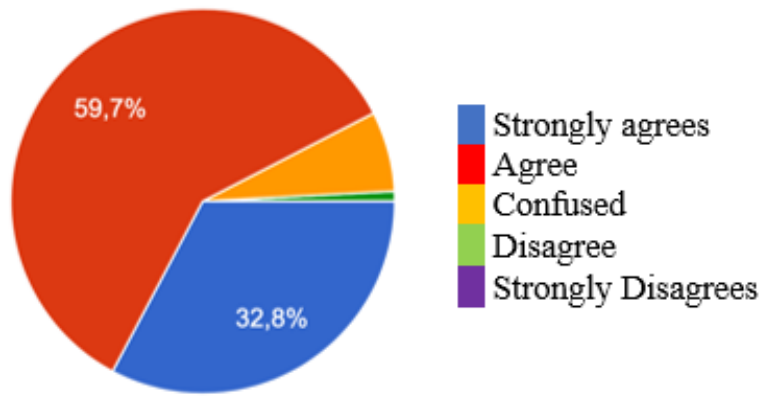

Figure 6. The contents encourage students to act positive impacts

In addition, the content of Pancasila on mobile learning application can also improve the feeling of positive ses among the students. They can act a positive impact after learning Pancasila on the mobile application. For example, students can take a look to the book, or call their friends to discuss with them.

\section{Conclusions}

Mobile learning (m-learning) is learning that utilizes technology and mobile devices. In this case, the device can be a PDA, cell phone, laptop, tablet PC, and so on. With mobile learning, users can access learning content anywhere and anytime, without having to visit a certain place at a certain time. So, users can access educational content without being bound by time and space.

There are three functions of Mobile Learning in learning activities in the classroom (classroom instruction), namely as a supplementary (optional) which is optional (optional), complementary (complementary), or substitute (substitution). Mobile Learning can be utilized and developed in shaping a new learning culture that is more modern, democratic and educational. Learning culture is a small part of the culture of society. Community culture is defined as the integration of all objects, ideas, knowledge, institutions, ways of doing things, habits, patterns of behavior, values, and attitudes of each generation in a society.

In addition to being a source of learning, the use of mobile learning applications can also improve the empathy character of students. It can be seen from the communication and cooperation that it is established by students in learning the learning content. One of the values that can be taken in learning by using mobile learning is that students can carry out positive activities that can lead to empathy values. Mobile Learning is expected to be an alternative learning resource that can improve the efficiency and effectiveness of the learning process and learning outcomes of students in Indonesia in the future.

\section{REFERENCES}

[1] Abdulkarim, A., Komalasari, K., Saripudin, D., \& Anggraini, D. N. (2020). Development of a Unity in Diversity-Based Pancasila Education Text Book for Indonesian Universities. International Journal of Instruction, 13(1).

[2] Aguayo, C., Cochrane, T., \& Narayan, V. (2017). Key Themes in Mobile Learning: Prospects for Learner-Generated Learning through AR and VR. Australasian Journal of Educational Technology, 33(6).

[3] Alasmari, T., \& Zhang, K. (2019). Mobile Learning Technology Acceptance in Saudi Arabian Higher Education: An Extended Framework and a Mixed-Method Study. Education and Information Technologies, 24(3), 2127-2144.

[4] Anohah, E., Oyelere, S. S., \& Suhonen, J. (2017). Trends of Mobile Learning in Computing Education from 2006 to 2014: A Systematic Review of Research Publications. International Journal of Mobile and Blended Learning (IJMBL), 9(1), 16-33.

[5] Bai, H. (2019). Pedagogical Practices of Mobile Learning in K-12 and Higher Education Settings. TechTrends, 63(5), 611-620.

[6] Benali, M., \& Ally, M. (2020). Towards a Conceptual Framework Highlighting Mobile Learning Challenges. International Journal of Mobile and Blended Learning (IJMBL), 12(1), 51-63.

[7] Bullough Jr, R. V. (2019). Empathy, Teaching Dispositions, Social Justice and Teacher Education. Teachers and Teaching, 25(5), 507-522.

[8] Cohen, L., Manion, L., \& Morrison, K. (2013). Research methods in education. London: Routledge. 
[9] Crompton, H., \& Burke, D. (2018). The use of mobile learning in higher education: A systematic review. Computers \& Education, 123, 53-64.

[10] Cuzzo, M. S., Larson, M. R., \& Mattsso, L. M. (2017). How Do You Effectively Teach Empathy to Students? New Directions for Teaching and Learning(151), 61-78.

[11] Dolawattha, D. M., Pramadasa, H. S., \& Jayaweer. (2019). The Impact Model: Teachers' Mobile Learning Adoption in Higher Education. International Journal of Education and Development using Information and Communication Technology, 15(4), 71-88.

[12] Fitch, R. M., \& Webb, S. A. (1989). Cultural Immersion in Indonesia through Pancasila: State Ideology. The Journal of Educational Thought (JET)/Revue de la Pensée Éducative, 44-51.

[13] Grant, M. M. (2019). Difficulties in defining mobile learning: analysis, design characteristics, and implications. Educational Technology Research and Development, 67(2), 361-388.

[14] Kaliisa, R., \& Michelle, P. (2019). Mobile learning policy and practice in Africa: Towards inclusive and equitable access to higher education. Australasian Journal of Educational Technology, 35(6), 1-14.

[15] Kärki, T., Keinänen, H., Tuominen, A., \& Hoikkala, M. (2018). Meaningful Learning with Mobile Devices: Pre-Service Class Teachers' Experiences of Mobile Learning in the Outdoors. Technology, Pedagogy and Education, 27(2), 251-263.

[16] Komarudin, K., Alkhudri, A. T., Ubedilah, U., Syaifudin, S., \& Casmana, A. R. (2019). The nationality education model: the implementation of a score-a training model for youth across different cultures in Indonesia. Journal of Social Studies Education Research, 10(2), 308-322.

[17] Martin, F., \& Ertzberger, J. (2013). Here and now mobile learning: An experimental study on the use of mobile technology. Computers \& Education, 68, 76-85.

[18] Marwan, M. E., Madar, A. R., \& Fuad, N. (2013). An overview of mobile application in learning for student of Kolej Poly-Tech Mara (KPTM) by using mobile phone. Journal of Asian Scientific Research, 3(6), 527.

[19] Meyers, S., Rowell, K., Wells, M., \& Smith, B. C. (2019). Teacher Empathy: A Model of Empathy for Teaching for Student Success. College Teaching, 67(3), 160-168.

[20] Moorthy, K., Yee, T. T., T'ing, L. C., \& Kumaran, V. V. (2019). Habit and Hedonic Motivation Are the Strongest Influences in Mobile Learning Behaviours among Higher Education Students in Malaysia. Australasian Journal of Educational Technology, 35(4).

[21] Morfit, M. (1981). Pancasila: The Indonesian state ideology according to the new order government. Asian Survey, 21(8), 838-851.

[22] Mul, C. L., Stagg, S. D., Herbelin, B., \& Aspell. (2018). The feeling of me feeling for you: Interoception, alexithymia and empathy in autism. Journal of Autism and Developmental Disorders, 48(9), 2953-2967.

[23] Nishimura, S. (1995). The development of Pancasila moral education in Indonesia. Japanese Journal of Southeast Asian Studies, 33(5), 303-316.

[24] Nurdin, E. S. (2015). The Policies on Civic Education in Developing National Character in Indonesia. International Education Studies, 8(8), 199-209.

[25] Park, S. Y., Lee, H. D., \& Kim, S. Y. (2018). South Korean University Students' Mobile Learning Acceptance and Experience Based on the Perceived Attributes, System Quality and Resistance. Innovations in Education and Teaching International, 55(4), 450-458.

[26] Rockwell, A., Vidmar, C. M., Harvey, P., \& Greenwo, L. (2019). Do Sociology Courses Make More Empathetic Students? A Mixed-Methods Study of Empathy Change in Undergraduates. Teaching Sociology, 47(4), 284-302.

[27] Sarkadi, Casmana, A. R., \& Rahmawati, Y. (2020). Improved Learning Design for Pre-Service Teacher in a Character Education Course. Universal Journal of Education Research, 212-224. DOI: 10.13189/ujer.2020.080126.

[28] Sarkadi, \& Casmana, A. R. (2020). The Application of Empathetic Learning in Facing the Covid-19 Pandemic as the Responsibility of Good Citizens. International Journal of Psychosocial Rehabilitation, 24(9), 1475-7192.

[29] Suhadi, Syafrudin, I., \& Casmana, A. R. (2020). The Political Culture of the Cigugur Society, Indonesia. International Journal of Psychosocial Rehabilitation, 24(9), 1168-1175.

[30] Sumadi, T., \& Casmana, A. R. (2020). The Importance of Social Competences Transformation towards Early Age Children in Jakarta. Universal Journal of Educational Research, 8(5), 1991-1996. doi:10.13189/ujer.2020.080536

[31] Traxler, J. (2009). Learning in a mobile age. International Journal of Mobile and Blended Learning (IJMBL), 1(1), $1-12$.

[32] Yang, S., Zhou, S., \& Cheng, X. (2019). Why Do College Students Continue to Use Mobile Learning? Learning Involvement and Self-Determination Theory. British Journal of Educational Technology, 50(2), 626-637.

[33] Zid, M., Alkhudri, A. T., Casmana, A. R., Marini, A., \& Wahyudi, A. (2020). Ex Migrant Workers of International Women and Social Entrepreneurship: Study at Kenanga Village in Indramayu Regency in West Java Province in Indonesia. International Journal of Advanced Science and Technology, 29(06), 1855-1861.

[34] Zid, M., Casmana, A. R., \& Hijrawadi, S. N. (2020). The Development of International Education towards Migration Abroad by Indonesian Women. Universal Journal of Educational Research, 8(5), 1953-1963. doi:DOI: 10.13189/ujer.2020.08053 